\title{
11. HIGH-RESOLUTION, WHOLE-CORE MAGNETIC SUSCEPTIBILITY DATA FROM LEG 130, ONTONG JAVA PLATEAU1
}

\author{
John A. Tarduno, ${ }^{2}$ Larry A. Mayer, ${ }^{3}$ Robert Musgrave, ${ }^{4}$ and Shipboard Scientific Party ${ }^{5}$
}

\begin{abstract}
High-resolution, whole-core magnetic susceptibility data, recorded at 3-cm intervals, were obtained for advanced hydraulic piston (APC) cores at Sites 805,806 , and 807 of Leg 130 on the Ontong Java Plateau. In this initial report, we present a preliminary evaluation of these data for their use in core correlations and paleoclimatic studies. The data allow detailed intrasite correlations between the offset APC cores and provide a means for intersite correlations of Pleistocene sediments. Variations in magnetic susceptibility values probably mirror variations in terrestrial influx and may act as proxy indicators of climate. Highly coherent cyclicity, representing Milankovitch orbital frequencies, is exhibited in some intervals and provides the potential to tune sedimentation rates. Postdepositional dissolution of magnetite by reduction diagenesis, which is also reflected in the magnetic susceptibility data, may be a limiting factor in these studies.
\end{abstract}

\section{INTRODUCTION}

Variations in rock magnetic parameters commonly reflect changes in terrestrial influx that can be related to environmental change (Thompson et al., 1980; Thompson and Oldfield, 1986). One of the principal goals of high-resolution magnetic susceptibility measurements during Ocean Drilling Program (ODP) Leg 130 was to determine whether the recovered sediments contained a climatically driven rock-magnetic signature. As such records commonly provide fine detail, they also provide a means of correlating the various sites as well as the offset advanced hydraulic piston (APC) cores at a single site (e.g., Bloemendal et al., 1988b).

The Ontong Java Plateau is an ideal setting to obtain a magnetic susceptibility record that reflects climatic change. The bathymetry of the plateau has produced a stable sedimentary environment that probably preserves global signals rather than the local events that have been a limiting factor in previous efforts to obtain a rock-magnetic characterization of glacial-interglacial cycles (e.g., King, 1986). The near-equatorial position of the Leg 130 sites has resulted in the accumulation of a thick Neogene sequence of calcium-carbonate-rich sediments thought to record major paleoceanographic changes by means of calcite dissolution gradients. Therefore, the influence of diamagnetic calcite is expected to be especially pronounced in these sediments.

Two other factors that are not the products of variations in terrestrial influx can also influence magnetic susceptibility (e.g., Hall et al., 1989). First, the production of magnetite in the single-domain size range by magnetotactic bacteria can be an important process in deep-sea sediments (Kirschvink and Chang, 1984; Petersen et al., 1986; Stoltz et al., 1986; Worm and Weinreich, 1988). These particles sometimes-display distinctive shapes. Recent rock-magnetic experiments conducted on piston cores from the Ontong Java Plateau (Tauxe and Wu, 1990) have

\footnotetext{
${ }^{1}$ Kroenke, L. W., Berger, W. H., Janecek, T. R., et al., 1991. Proc. ODP, Init. Repts., 130: College Station, TX (Ocean Drilling Program).

2 Scripps Institution of Oceanography, University of California, San Diego, La Jolla, CA 92093-0215, U.S.A.

${ }^{3}$ Department of Oceanography, Dalhousie University, Halifax, Nova Scotia, Canada B3H $4 \mathrm{~J} 1$.

${ }^{4}$ Geology Department, The University of Tasmania, G.P.O. Box $252 \mathrm{C}$, Hobart, Tasmania, 7001, Australia.

5 Shipboard Scientific Party is as given in the list of participants preceding the contents.
}

addressed this point. Although no magnetite with shapes characteristic of those produced by magnetotactic bacteria were observed, Tauxe and Wu (1990) did find compelling evidence for magnetite of pseudosingle domain size. The source of this magnetite could be volcanic grains as such particles were observed by transmission electron microscopy (Tauxe and Wu, 1990); however, other sources such as bacteria that produce magnetite extracellularly (Lovley et al., 1987) could not be excluded.

The second factor not directly related to terrestrial influx that can influence magnetic susceptibility measurements is postdepositional dissolution of magnetite by reduction diagenesis (Karlin, 1983; Karlin and Levi, 1983, 1985; Canfield and Berner, 1987). This process appears to be an important control on the magnetic polarity records (e.g., see "Paleomagnetics" section, "Site 805 " chapter, this volume) and, as discussed below, the magnetic susceptibility records for Leg 130 sites.

\section{INSTRUMENTATION AND METHODS}

Low-field volume magnetic susceptibility measurements of whole-core sections were taken with a Bartington Instruments Magnetic Susceptibility Meter (model MS1). Anomalously high drift exhibited by an initial loop sensor resulted in the use of two substitute sensor loops with different diameters and frequencies (Table 1). We used the automated shipboard multisensor track (MST) set at $3-\mathrm{cm}$ intervals and the $0.1 \times$ range of the Bartington meter to record all the measurements discussed in this report. At the $0.1 \times$ range, the magnetic susceptibility precision is $2 \times 10^{-7} \mathrm{cgs}$, using an 80 -mm sensor. The MST also includes measurements of $P$-wave velocity and saturated bulk density by means of the gamma-ray attenuation porosity evalua-

Table 1. Magnetic susceptibility sensor diameters and operating frequencies used during $\mathrm{Leg}$ 130.

\begin{tabular}{lllcl}
\hline Site & Cores & Sensor & $\begin{array}{c}\text { Diameter } \\
(\mathrm{mm})\end{array}$ & $\begin{array}{c}\text { Frequency } \\
(\mathrm{kHz})\end{array}$ \\
\hline $805 \mathrm{~A}$ & $1 \mathrm{H}-4 \mathrm{H}$ & MS1C & 100 & 0.86 \\
$805 \mathrm{C}$ & $1 \mathrm{H}-2 \mathrm{H}$ & MS1C & 100 & 0.86 \\
$806 \mathrm{~A}$ & $1 \mathrm{H}-4 \mathrm{H}$ & MS1C & 100 & 0.86 \\
$806 \mathrm{~A}$ & $1 \mathrm{H}-9 \mathrm{H}$ & MS2C & 80 & 0.565 \\
$806 \mathrm{~B}$ & $1 \mathrm{H}-8 \mathrm{H}$ & MS1C & 100 & 0.86 \\
$806 \mathrm{C}$ & $1 \mathrm{H}-21 \mathrm{H}$ & MS2C & 80 & 0.565 \\
$807 \mathrm{~A}$ & $1 \mathrm{H}-27 \mathrm{H}$ & MS2C & 80 & 0.565 \\
$807 \mathrm{~B}$ & $1 \mathrm{H}-30 \mathrm{H}$ & MS2C & 80 & 0.565 \\
\hline
\end{tabular}


tor (GRAPE). Background measurements were taken before and after the measurement of each core section. The measurement time for one $1.5-\mathrm{m}$ core section, with the $P$-wave and GRAPE data also collected, was $13 \mathrm{~min}$.

The data were collected on a DEC PRO 350 microcomputer and stored on floppy diskettes. After transferal to a VAX 11/ 750 computer, the background readings for each section were used to calculate a linear drift correction. Raw data were calibrated for a sensor diameter of $80 \mathrm{~mm}$ using a $\mathrm{MnO}_{2}$ standard. The values derived from the use of the 100 -mm sensor were adjusted by measuring the same standard and calculating a correction factor (2.7) relative to the 80 -mm sensor. The difference in frequency between the two sensors used is negligible for the expected range of contributions to the susceptibility of Leg 130 sediments. Sensor diameter, however, could influence the resolving power of the measured data. Therefore, raw data were collected on the same interval from Hole 806A (Cores 130-806A$1 \mathrm{H}$ to $-4 \mathrm{H}$ ) with the two different sensors for a sensitivity comparison.

\section{RESULTS}

Volume magnetic susceptibility values from Sites 805,806 , and 807 are generally low (less than $10 \times 10^{-6} \mathrm{cgs}$ ), probably reflecting a low ferrimagnetic content as well as a high diamagnetic calcium carbonate content. Nevertheless, a distinct series of variations are present in the data from Pleistocene sediments at all sites, allowing detailed correlations between offset APC cores.

Anomalously high values of magnetic susceptibility are commonly associated with sediment located $10-20 \mathrm{~cm}$ below or above core breaks. The origin of these magnetic susceptibility "spikes" is visible rust contamination, a common feature in some APC cores (Sager, 1986, 1988). Such contamination was not observed far from the core breaks within the APC cores. Artifacts in the magnetic susceptibility data caused by such contamination can easily be addressed by filtering these values in future studies.

The high-amplitude variations in magnetic susceptibility exhibit rapid decay at a sub-bottom depth that is the same in the offset APC holes of a single site but different between sites (Fig. 1 , back pocket). This depth also corresponds to the level at which the intensity of magnetic remanence decays by several orders of magnitude and directional information useful for paleomagnetic polarity determinations is lost. The cause of this transition in the character of the magnetic susceptibility signal appears to be postdepositional dissolution of magnetite by reduction diagenesis (Karlin, 1983; Karlin and Levi, 1983, 1985; Canfield and Berner, 1987). Rather than being a gradual transition, the proposed dissolution manifests itself as an abrupt drop in magnetic susceptibility values, perhaps related to the point at which buffers to reduction diagenesis are exceeded. This scenario is further supported by the interstitial water geochemistry from these sites, which shows a decrease in $\mathrm{SO}_{4}^{-2}$ concentration at a depth (see the "Inorganic Geochemistry" sections of Sites 805,806 , and 807 ) that coincides with the drop in magnetic remanence (see the "Paleomagnetics" sections of Sites 806 and 807). The variable water depths and latitudes (and, therefore, the distance from the equatorial zone of upwelling) appear directly related to the depth at which the magnetic susceptibility data exhibit the prominent decrease.

Correlation of the paleomagnetic record cannot be continued below the abrupt drop in magnetic remanence, but correlatable variations in susceptibility are sometimes present below this depth. The magnetic susceptibility decrease, however, does lower the measured susceptibility values much closer to the precision of the sensors used in this study and therefore represents an inherent limitation of the data. The features of the magnetic sus- ceptibility data that can be correlated at each site are summarized below.

\section{Site 805}

The limited high-resolution magnetic susceptibility data from Site 805 allow detailed correlation of Holes $805 \mathrm{~A}$ and $805 \mathrm{C}$ down to $10 \mathrm{~m}$ below seafloor (mbsf) (Table 2 and Fig. 2, back pocket). Above $3 \mathrm{mbsf}$, the offset between the two holes is approximately $20 \mathrm{~cm}$. This offset increases to $39-40 \mathrm{~cm}$ at $3 \mathrm{mbsf}$, presumably because of material lost in the core break in Hole 805A.

\section{Site $\mathbf{8 0 6}$}

Distinct variations in magnetic susceptibility values above 10.5 mbsf allow detailed correlations between the offset holes at Site 806 (Fig. 3, back pocket). For correlation purposes, data collected with the $80-\mathrm{mm}$ Bartington MS2C sensor (Table 1) from Holes $806 \mathrm{~A}$ and $806 \mathrm{C}$ were compared with each other as well as with data from Hole $806 \mathrm{~B}$ collected using the 100 -mm Bartington MS1C sensor. This comparison allows the Site 806 section to be divided into four intervals separated by core breaks (Table 3). Differences in sub-bottom depth between the cores are always less than $0.7 \mathrm{~m}$. Variations within a correlated interval may reflect differential compaction (or expansion) during recovery.

An additional interval can be correlated between Holes 806A and $806 \mathrm{C}$, below the prominent drop in magnetic susceptibility values in these holes at 10.48 and 10.60 mbsf, respectively. Hole $806 \mathrm{~B}$ has higher magnetic susceptibility values within this interval, different from those observed at either Hole 806A or Hole $806 \mathrm{C}$. The data for Hole 806B, however, were collected with the 100 -mm sensor, which, as discussed further below, appears to have less resolution than those collected with the $80-\mathrm{mm}$ sensor.

\section{Comparison of Data from Hole 806A Using 80- and 100-mm Sensors}

A comparison of the 80 - and $100-\mathrm{mm}$ Bartington sensors (Fig. 4, back pocket) was made using cores from Hole 806A. The records from the two sensors are nearly identical above $10.48 \mathrm{mbsf}$ but differ at greater sub-bottom depths. In particular, the 100-mm sensor appears to have low- and high-frequency characteristics not observed in the data using the $80-\mathrm{mm}$ sensor. When these data sets are next compared with the data collected with the 80 -mm Bartington sensor on Hole $806 \mathrm{C}$ (Fig. 4, back pocket), it is clear that these characteristics are unique to the

Table 2. Correlation between Holes $805 \mathrm{~A}$ and $805 \mathrm{C}$ based on wholeround magnetic susceptibility measurements.

\begin{tabular}{cllcccc}
\hline Correlation & Type & $\begin{array}{c}\text { Hole, } \\
\text { Core }\end{array}$ & $\begin{array}{c}\text { Depth } \\
\text { (mbsf) }\end{array}$ & $\begin{array}{c}\text { Hole, } \\
\text { Core }\end{array}$ & $\begin{array}{c}\text { Depth } \\
\text { (mbsf) }\end{array}$ & A-C \\
\hline A1 & Peak & $805 \mathrm{~A}-1 \mathrm{H}$ & 0.47 & $805 \mathrm{C}-1 \mathrm{H}$ & 0.41 & 0.06 \\
A2 & Peak & $805 \mathrm{~A}-1 \mathrm{H}$ & 1.28 & $805 \mathrm{C}-1 \mathrm{H}$ & 1.10 & 0.18 \\
A3 & Peak & $805 \mathrm{~A}-1 \mathrm{H}$ & 1.91 & $805 \mathrm{C}-1 \mathrm{H}$ & 1.73 & 0.18 \\
A4 & Peak & $805 \mathrm{~A}-1 \mathrm{H}$ & 2.18 & $805 \mathrm{C}-1 \mathrm{H}$ & 1.97 & 0.21 \\
A5 & Peak & $805 \mathrm{~A}-1 \mathrm{H}$ & 2.60 & $805 \mathrm{C}-1 \mathrm{H}$ & 2.39 & 0.21 \\
& & Core break & 3.00 & & & \\
B1 & Peak & $805 \mathrm{~A}-2 \mathrm{H}$ & 3.35 & $805 \mathrm{C}-1 \mathrm{H}$ & 2.96 & 0.39 \\
B2 & Trough & $805 \mathrm{~A}-2 \mathrm{H}$ & 4.25 & $805 \mathrm{C}-1 \mathrm{H}$ & 3.86 & 0.39 \\
B3 & Peak & $805 \mathrm{~A}-2 \mathrm{H}$ & 4.43 & $805 \mathrm{C}-1 \mathrm{H}$ & 4.04 & 0.39 \\
B4 & Peak & $805 \mathrm{~A}-2 \mathrm{H}$ & 5.15 & $805 \mathrm{C}-1 \mathrm{H}$ & 4.79 & 0.36 \\
B5 & Peak & $805 \mathrm{~A}-2 \mathrm{H}$ & 5.54 & $805 \mathrm{C}-1 \mathrm{H}$ & 5.21 & 0.33 \\
B6 & Trough & $805 \mathrm{~A}-2 \mathrm{H}$ & 5.75 & $805 \mathrm{C}-1 \mathrm{H}$ & 5.45 & 0.30 \\
B7 & Peak & $805 \mathrm{~A}-2 \mathrm{H}$ & 7.04 & $805 \mathrm{C}-1 \mathrm{H}$ & 6.68 & 0.36 \\
B8 & Trough & $805 \mathrm{~A}-2 \mathrm{H}$ & 7.28 & $805 \mathrm{C}-1 \mathrm{H}$ & 6.92 & 0.36 \\
B9 & Peak & $805 \mathrm{~A}-2 \mathrm{H}$ & 7.76 & $805 \mathrm{C}-1 \mathrm{H}$ & 7.40 & 0.36 \\
& & & & Core break & 7.80 & \\
\hline
\end{tabular}

Note: See Figure 2 for locations of correlative peaks and troughs. 
Table 3. Correlation between Holes $806 \mathrm{~A}, 806 \mathrm{C}$, and $806 \mathrm{~B}$ based upon whole-round magnetic susceptibility measurements.

\begin{tabular}{|c|c|c|c|c|c|c|c|c|c|c|}
\hline Correlation & Type & $\begin{array}{l}\text { Hole, } \\
\text { Core }\end{array}$ & $\begin{array}{l}\text { Depth } \\
\text { (mbsf) }\end{array}$ & $\begin{array}{l}\text { Hole, } \\
\text { Core }\end{array}$ & $\begin{array}{l}\text { Depth } \\
\text { (mbsf) }\end{array}$ & $\begin{array}{c}\text { Hole, } \\
\text { Core }\end{array}$ & $\begin{array}{l}\text { Depth } \\
\text { (mbsf) }\end{array}$ & A-C & A-B & B-C \\
\hline Al & Peak & 806A-1H & 0.38 & $806 \mathrm{C}-1 \mathrm{H}$ & 0.47 & 806B-1H & 0.53 & -0.0 & -0.15 & 0.06 \\
\hline A2 & Peak & $806 \mathrm{~A}-1 \mathrm{H}$ & 0.89 & $806 \mathrm{C}-1 \mathrm{H}$ & 1.40 & $806 \mathrm{~B}-1 \mathrm{H}$ & - & -0.15 & - & \\
\hline A3 & Trough & $806 \mathrm{~A}-1 \mathrm{H}$ & 1.07 & $806 \mathrm{C}-1 \mathrm{H}$ & 1.19 & $806 \mathrm{~B}-1 \mathrm{H}$ & 1.25 & -0.12 & -0.18 & 0.06 \\
\hline A4 & Peak & $806 \mathrm{~A}-1 \mathrm{H}$ & 1.22 & $806 \mathrm{C}-1 \mathrm{H}$ & 1.37 & $806 \mathrm{~B}-1 \mathrm{H}$ & - & -0.15 & - & \\
\hline As & Trough & $806 \mathrm{~A}-1 \mathrm{H}$ & 1.49 & $806 \mathrm{C}-1 \mathrm{H}$ & 1.49 & $806 \mathrm{~B}-1 \mathrm{H}$ & 1.73 & 0.00 & -0.24 & 0.24 \\
\hline A6 & Peak & $806 \mathrm{~A}-1 \mathrm{H}$ & 2.18 & $806 \mathrm{C}-1 \mathrm{H}$ & 2.39 & $806 \mathrm{~B}-1 \mathrm{H}$ & 2.36 & -0.21 & -0.18 & -0.03 \\
\hline A7 & Trough & $806 \mathrm{~A}-1 \mathrm{H}$ & 2.33 & $806 \mathrm{C}-1 \mathrm{H}$ & 2.51 & $806 \mathrm{~B}-1 \mathrm{H}$ & 2.66 & -0.18 & -0.33 & 0.15 \\
\hline A8 & Peak & $806 \mathrm{~A}-1 \mathrm{H}$ & 2.51 & $806 \mathrm{C}-1 \mathrm{H}$ & 2.75 & $806 \mathrm{~B}-1 \mathrm{H}$ & 2.81 & -0.24 & -0.30 & 0.06 \\
\hline A9 & Trough & $806 \mathrm{~A}-1 \mathrm{H}$ & 2.81 & $806 \mathrm{C}-1 \mathrm{H}$ & 3.11 & $806 \mathrm{~B}-1 \mathrm{H}$ & 3.17 & -0.30 & -0.36 & 0.06 \\
\hline A10 & Peak & $806 \mathrm{~A}-1 \mathrm{H}$ & 2.93 & $806 \mathrm{C}-1 \mathrm{H}$ & 3.29 & $806 \mathrm{~B}-1 \mathrm{H}$ & 3.26 & -0.36 & -0.33 & -0.03 \\
\hline A11 & Trough & $806 \mathrm{~A}-1 \mathrm{H}$ & 3.17 & $806 \mathrm{C}-1 \mathrm{H}$ & 3.50 & $806 \mathrm{~B}-1 \mathrm{H}$ & 3.56 & -0.33 & -0.39 & 0.06 \\
\hline $\mathrm{A} 12$ & Peak & $806 \mathrm{~A}-1 \mathrm{H}$ & 3.44 & $806 \mathrm{C}-1 \mathrm{H}$ & 3.77 & $806 \mathrm{~B}-1 \mathrm{H}$ & 3.92 & -0.33 & -0.48 & 0.15 \\
\hline A13 & Peak & $806 \mathrm{~A}-1 \mathrm{H}$ & 3.80 & $806 \mathrm{C}-1 \mathrm{H}$ & 4.13 & $806 \mathrm{~B}-1 \mathrm{H}$ & - & -0.33 & - & \\
\hline A14 & Trough & $806 \mathrm{~A}-1 \mathrm{H}$ & 4.01 & $806 \mathrm{C}-1 \mathrm{H}$ & 4.49 & $806 \mathrm{~B}-1 \mathrm{H}$ & - & -0.48 & - & \\
\hline A 15 & Peak & $806 \mathrm{~A}-1 \mathrm{H}$ & 4.40 & $806 \mathrm{C}-1 \mathrm{H}$ & 4.79 & $806 \mathrm{~B}-1 \mathrm{H}$ & 4.85 & -0.39 & -0.45 & 0.06 \\
\hline A16 & Trough & $806 \mathrm{~A}-1 \mathrm{H}$ & 4.49 & $806 \mathrm{C}-1 \mathrm{H}$ & 5.00 & $806 \mathrm{~B}-1 \mathrm{H}$ & 5.06 & -0.51 & -0.57 & 0.06 \\
\hline \multirow[t]{2}{*}{ A 17} & Trough & 806A-1H & 4.82 & $806 \mathrm{C}-1 \mathrm{H}$ & 5.30 & $806 \mathrm{~B}-1 \mathrm{H}$ & 5.33 & -0.48 & -0.51 & 0.03 \\
\hline & & & & Core break & 5.60 & & & & & \\
\hline B1 & Trough & $806 \mathrm{~A}-1 \mathrm{H}$ & 5.42 & $806 \mathrm{C}-2 \mathrm{H}$ & 5.95 & $806 \mathrm{~B}-1 \mathrm{H}$ & 5.93 & -0.53 & -0.51 & -0.02 \\
\hline B2 & Peak & $806 \mathrm{~A}-1 \mathrm{H}$ & 5.48 & $806 \mathrm{C}-2 \mathrm{H}$ & 6.04 & $806 \mathrm{~B}-1 \mathrm{H}$ & 5.96 & -0.56 & -0.48 & -0.08 \\
\hline \multirow[t]{2}{*}{ B3 } & Peak & $806 \mathrm{~A}-1 \mathrm{H}$ & 5.84 & $806 \mathrm{C}-2 \mathrm{H}$ & 6.28 & $806 \mathrm{~B}-1 \mathrm{H}$ & - & -0.44 & - & \\
\hline & & & & & & Core break & 6.50 & & & \\
\hline $\mathrm{Cl}$ & Peak & $806 \mathrm{~A}-1 \mathrm{H}$ & 6.35 & $806 \mathrm{C}-2 \mathrm{H}$ & 6.70 & $806 \mathrm{~B}-2 \mathrm{H}$ & 7.00 & -0.35 & -0.65 & 0.30 \\
\hline $\mathrm{C} 2$ & Trough & $806 \mathrm{~A}-1 \mathrm{H}$ & 6.56 & $806 \mathrm{C}-2 \mathrm{H}$ & 7.00 & $806 \mathrm{~B}-2 \mathrm{H}$ & 7.21 & -0.44 & -0.65 & 0.21 \\
\hline $\mathrm{C} 3$ & Peak & $806 \mathrm{~A}-1 \mathrm{H}$ & 7.31 & $806 \mathrm{C}-2 \mathrm{H}$ & 7.57 & $806 \mathrm{~B}-2 \mathrm{H}$ & 7.93 & -0.26 & -0.62 & 0.36 \\
\hline \multirow[t]{2}{*}{$\mathrm{C} 4$} & Peak & $806 \mathrm{~A}-1 \mathrm{H}$ & 7.43 & $806 \mathrm{C}-2 \mathrm{H}$ & 7.72 & $806 \mathrm{~B}-2 \mathrm{H}$ & 8.11 & -0.29 & -0.68 & 0.39 \\
\hline & & Core break & 7.70 & & & & & & & \\
\hline D1 & Peak & $806 \mathrm{~A}-2 \mathrm{H}$ & 8.17 & $806 \mathrm{C}-2 \mathrm{H}$ & 8.32 & $806 \mathrm{~B}-2 \mathrm{H}$ & 8.77 & -0.15 & -0.60 & 0.45 \\
\hline D2 & Peak & $806 \mathrm{~A}-2 \mathrm{H}$ & 8.47 & $806 \mathrm{C}-2 \mathrm{H}$ & 8.68 & $806 \mathrm{~B}-2 \mathrm{H}$ & 9.10 & -0.21 & -0.63 & 0.42 \\
\hline D3 & Trough & $806 \mathrm{~A}-2 \mathrm{H}$ & 8.71 & $806 \mathrm{C}-2 \mathrm{H}$ & 8.86 & $806 \mathrm{~B}-2 \mathrm{H}$ & 9.28 & -0.15 & -0.57 & 0.42 \\
\hline D4 & Peak & $806 \mathrm{~A}-2 \mathrm{H}$ & 9.40 & $806 \mathrm{C}-2 \mathrm{H}$ & 9.55 & $806 \mathrm{~B}-2 \mathrm{H}$ & 9.97 & -0.15 & -0.57 & 0.42 \\
\hline D5 & Peak & $806 \mathrm{~A}-2 \mathrm{H}$ & 9.79 & $806 \mathrm{C}-2 \mathrm{H}$ & 9.91 & $806 \mathrm{~B}-2 \mathrm{H}$ & 10.36 & -0.12 & -0.57 & 0.45 \\
\hline D6 & Trough & $806 \mathrm{~A}-2 \mathrm{H}$ & 10.48 & $806 \mathrm{C}-2 \mathrm{H}$ & 10.60 & $806 \mathrm{~B}-2 \mathrm{H}$ & 10.90 & -0.12 & -0.42 & 0.30 \\
\hline E1 & Peak & $806 \mathrm{~A}-2 \mathrm{H}$ & 10.81 & $806 \mathrm{C}-2 \mathrm{H}$ & 11.02 & & & -0.21 & & \\
\hline E2 & Peak & $806 \mathrm{~A}-2 \mathrm{H}$ & 11.47 & $806 \mathrm{C}-2 \mathrm{H}$ & 11.59 & & & -0.12 & & \\
\hline E3 & Peak & $806 \mathrm{~A}-2 \mathrm{H}$ & 13.36 & $806 \mathrm{C}-2 \mathrm{H}$ & 13.51 & & & -0.15 & & \\
\hline E4 & Peak & $806 \mathrm{~A}-2 \mathrm{H}$ & 13.78 & $806 \mathrm{C}-2 \mathrm{H}$ & 13.90 & & & -0.12 & & \\
\hline E5 & Peak & $806 \mathrm{~A}-2 \mathrm{H}$ & 14.32 & $806 \mathrm{C}-2 \mathrm{H}$ & 14.44 & & & -0.12 & & \\
\hline
\end{tabular}

Note: See Figure 3 for locations of correlative peaks and troughs.

100-mm sensor. These features, which may be some combination of long-term drift and noise, suggest that magnetic susceptibility values below $2 \times 10^{-6} \mathrm{cgs}$ using the 100 -mm sensor should be interpreted with considerable caution.

\section{Cyclicity in the Site 806 Magnetic Susceptibility Data}

Intervals in the high-resolution data from Holes 806A and $806 \mathrm{C}$, below the large decrease in magnetic susceptibility, exhibit cyclic variations. These variations are especially apparent in Core 130-806A-4H (Fig. 5). To examine this cyclicity, spectral analyses were performed using the standard techniques adopted by the SPECMAP program. The result of this analysis for Core $130-806 \mathrm{~A}-4 \mathrm{H}$ (using the 80 -mm sensor) shows that the magnetic susceptibility data display a dominant period of approximately 41 k.y. (see "Sedimentation Rate" section, "Site 806" chapter, this volume, for age controls) (Fig. 6A). When this is compared to a composite profile of Pleistocene isotopic data sets representing an ice volume signal (Imbrie et al., 1984), it is clear how well these data match the 41-k.y. obliquity cycle. The lower resolution magnetic susceptibility data from the same core, collected with the 100 -mm sensor, were also analyzed (Fig. 6B). As expected from our initial observations, lower frequency energy not observed in the data collected with the $80-\mathrm{mm}$ sensor is present and is believed to be an artifact. Moreover, the 41-k.y. cycle is still clearly seen.

To test the apparent cyclicity in Core 130-806A-4H further, two other data sets were examined. First, magnetic susceptibility data from the equivalent core of Hole $806 \mathrm{C}$ (Core 130-806C-
4H) were also analyzed (Fig. 7). Again, a dominant 41-k.y. cycle was observed (Fig. 8) and a cross-correlation of the data from Cores $130-806 \mathrm{~A}-4 \mathrm{H}$ and $130-806 \mathrm{C}-4 \mathrm{H}$ shows the cycles to be highly coherent (Fig. 9). Second, GRAPE density data from Hole $806 \mathrm{C}$ were examined to see if a similar cyclicity was present in an independent data set. Again, a 41-k.y. cycle was observed together with other Milankovitch cycles (Fig. 10). The presence of the obliquity cycle in the magnetic susceptibility data suggests that the approach has potential for the tuning of sedimentation rates in the upper section at Site 806 .

\section{Site $\mathbf{8 0 7}$}

Distinct variations in whole-core magnetic susceptibility data above 30 mbsf allow a detailed correlation of Holes $807 \mathrm{~A}$ and 807B (Fig. 11, back pocket). Unlike Hole 806C, shifts in the correlated sub-bottom depths, which coincide with the core breaks, are often greater than $1 \mathrm{~m}$ (Fig. 12 and Table 4). Hole 807B displays higher susceptibility values between 16.0 and 24.0 mbsf than those observed at Hole $807 \mathrm{~A}$. Variations superimposed on these higher background values, however, correlate well with variations present in the data from Hole 807A.

\section{Correlation of Holes $805 \mathrm{C}$, 806A, and $807 \mathrm{~A}$}

To compare the magnetic susceptibility data between sites, the data from the offset holes at a given site first must be spliced together to avoid the problem of missing a section because of gaps at the core breaks. To examine whether sites could be correlated with the whole-round magnetic susceptibility data de- 


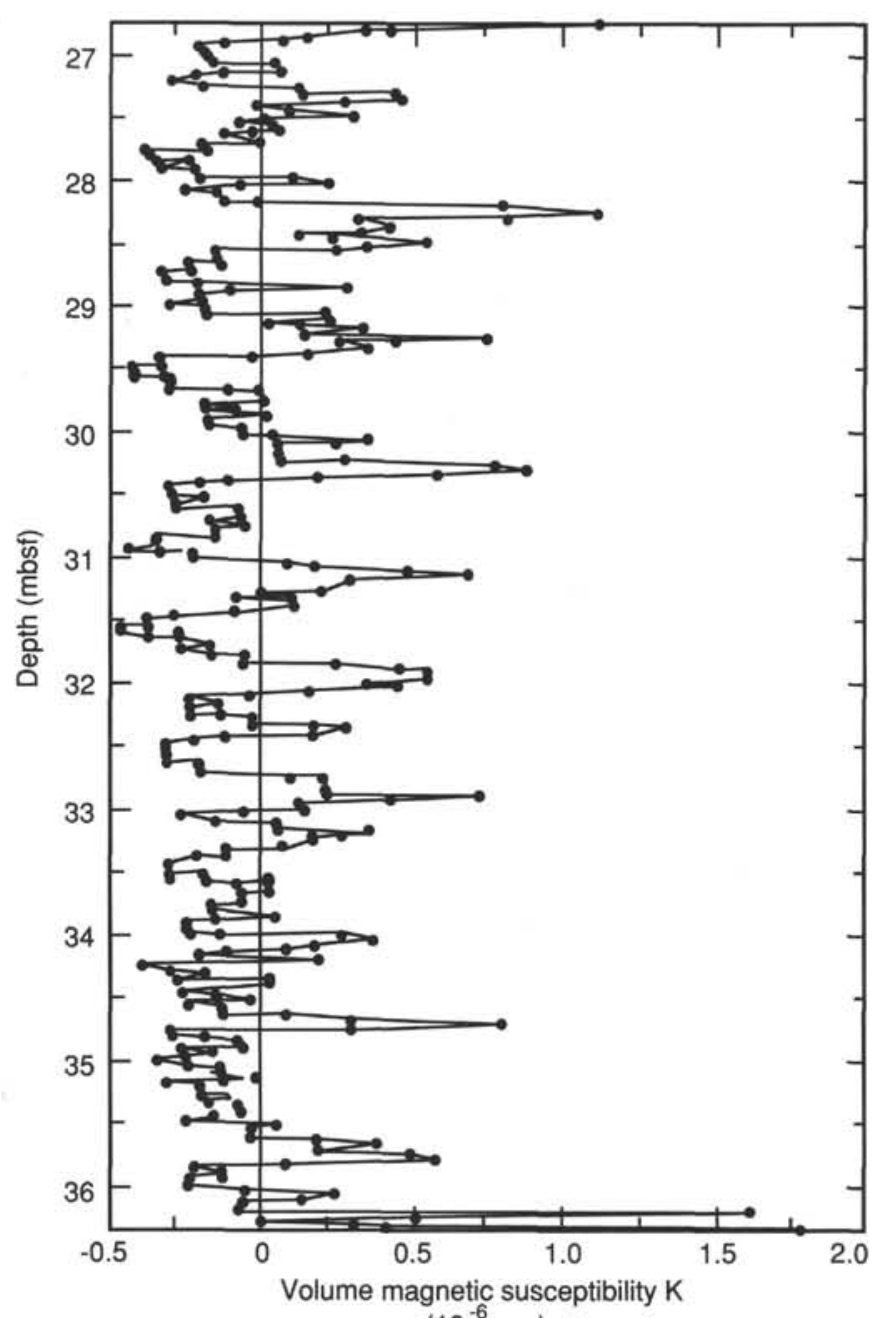

$\left(10^{-6} \mathrm{cgs}\right)$

Figure 5. Whole-core volume magnetic susceptibility record from Core 130-806A-4H exhibiting cyclic variations. High values below $36.0 \mathrm{mbsf}$ are probably caused by rust contamination at the core break.

scribed above, the first cores from one hole at each site were compared (Fig. 13, back pocket), avoiding the need to splice together records in this study. Each record shows a prominent drop in magnetic susceptibility values near $1.5 \mathrm{mbsf}$. Several other features appear to be common between the records, as shown in a preliminary correlation (Table 5).

\section{SUMMARY}

In this initial report, we evaluated the usefulness of the highresolution, whole-round magnetic susceptibility data collected during Leg 130 for core correlations and paleoclimatic studies. The data appear useful for both of these applications with certain limitations. These limitations and our preliminary observations and conclusions follow.

High-resolution volume magnetic susceptibility data were collected at Sites 805,806 , and 807 . Measured values decay rapidly at a sub-bottom depth that is common to the offset APC cores at a given site but different between sites. This rapid decay is probably a result of postdepositional dissolution of magnetite by reduction diagenesis (e.g., Karlin and Levi, 1983).

At sub-bottom depths shallower than the rapid drop in magnetic susceptibility, distinct fluctuations allow detailed correlation between the offset cores at a single site. The correlations re- cord differences in compaction and expansion within single cores created during coring and recovery and provide a means of measuring gaps in recovery caused by core breaks. Correlations are sometimes possible below the prominent drop in magnetic susceptibility, but the sensitivity of the sensor used to collect the data must also be considered.

A preliminary analysis of data from Core $130-806 \mathrm{~A}-4 \mathrm{H}$ shows that these data record at least the 41-k.y. obliquity cycle. This conclusion is supported by identifying this same cyclicity in another hole at an equivalent depth (Core 130-806C-4H) and by identifying similar cyclicity in an independent data set (i.e., the GRAPE data from Core 130-806C-4H). The interval from which these analyses were performed corresponds to the Matuyama Epoch, in which the 41-k.y. obliquity period in paleoclimatic data sets commonly dominates (Ruddiman et al., 1986a, 1986b; Henrich, 1989). The presence of orbitally driven frequencies in the magnetic susceptibility data suggest that such data have potential in tuning sedimentation rates. Furthermore, these magnetic susceptibility data may represent a near-continuous record of a paleoclimatic proxy.

It is tempting to speculate that the variations in magnetic susceptibility that can be correlated between sites are related to glacial-interglacial cycles, as observed in studies in the Atlantic (Robinson, 1986; Bloemendal et al., 1988a). A more definitive analyses of these data awaits the generation of high-resolution time scales using oxygen isotope variations. In addition, complementary rock magnetic analyses are needed to determine the probable contributors to the magnetic susceptibility signal, which may be different above and below the prominent magnetic susceptibility decrease.

\section{ACKNOWLEDGMENTS}

We thank ODP technicians Wendy Autio, Dave Cunningham, Ken du Vall, Matt Mefferd, Carie Rivers, Mark Simpson, Don Sims, Chuck Williamson, and the Leg 130 Shipboard Scientific Party for making many of the measurements described in this report.

\section{REFERENCES}

Bloemendal, J., Lamb, B., and King, J., 1988a. Paleoenvironmental implications of rock-magnetic properties of late Quaternary sediment cores from the eastern equatorial Atlantic. Paleoceanography, 3:6187.

Bloemendal, J., Tauxe, L., Valet, J.-P., and Shipboard Scientific Party, 1988b. High-resolution, whole-core magnetic susceptibility logs from Leg 108. In Ruddiman, W., Sarnthein, M., Baldauf, J., et al., Proc. ODP, Init. Repts., 108: College Station, TX (Ocean Drilling Program), 1005-1013.

Canfield, D. E., and Berner, R. A., 1987. Dissolution and pyritization of magnetite in anoxic marine sediments. Geochim. Cosmochim. Acta, 51:645-659.

Hall, F. R., Busch, W. H., and King, J. W., 1989. The relationship between variations in rock-magnetic properties and grain size of sediments from ODP Hole 645C. In Srivastava, S. P., Arthur, M., Clement, B., et al., Proc. ODP, Sci. Results, 105: College Station, TX (Ocean Drilling Program), 837-838.

Henrich, R., 1989. Glacial/interglacial cycles in the Norwegian Sea: sedimentology, paleoceanography, and evolution of late Pliocene to Quaternary Northern Hemisphere climate. In Eldholm, O., Thiede, J., Taylor, E., et al., Proc. ODP, Sci. Results, 104: College Station, TX (Ocean Drilling Program), 189-253.

Imbrie, J., Hays, J. D., Martinson, D. G., McIntyre, A., Mix, A. C., Morley, J. J., Pisias, N. G., Prell, W. L., and Shackleton, N. J., 1984. The orbital theory of Pleistocene climate: support from a revised chronology of the marine $\delta^{18} \mathrm{O}$ record. In Berger, A. L., Imbrie, J., Hays, J., Kukla, G., and Saltzman, B. (Eds.), Milankovitch and Climate: Understanding the Response to Astronomical Forcing (Vol. 1): Dordrecht-Boston-Lancaster (D. Riedel Publ. Co.), 269305 . 
Karlin, R., 1983. Paleomagnetism and diagenesis of hemipelagic sediments in the northeast Pacific Ocean and the Gulf of California [Ph.D. dissert.]. Oregon State Univ., Corvallis.

Karlin, R., and Levi, S., 1983. Diagenesis of magnetic minerals in recent hemipelagic sediments. Nature, 303:327-330.

1985. Geochemical and sedimentological control of the magnetic properties of hemipelagic sediments. J. Geophys. Res., 90: 10,373-10,392.

King, J. W., 1986. Paleomagnetic and rock-magnetic stratigraphy of Pigmy Basin, Deep Sea Drilling Project Site 619, Leg 96. In Bouma, A. H., Coleman, J. M., Meyer, A. W., et al., Init. Repts. DSDP, 96: Washington (U.S. Govt. Printing Office), 677-684.

Kirschvink, J. L., and Chang, S.-B. R., 1984. Ultrafine-grained magnetite in deep-sea sediments: possible bacterial magnetofossils. Geology, 12:559-562.

Lovley, D. R., Stolz, J. F., Nord, G. L., Jr., and Phillips, E.J.P., 1987. Anaerobic production of magnetite by a dissimilatory iron-reducing microorganism. Nature, 330:252-254.

Petersen, N., von Dobeneck, T., and Vali, H., 1986. Fossil bacterial magnetite in deep-sea sediments from the South Atlantic Ocean. Nature, 320:611-615.

Robinson, S. G., 1986. The late Pleistocene paleoclimatic record of North Atlantic deep-sea sediments revealed by mineral-magnetic measurements. Phys. Earth Planet. Int., 42:22-47.

Ruddiman, W. F., McIntyre, A., and Raymo, M., 1986a. Paleoenvironmental results from North Atlantic Sites 607 and 609. In Ruddiman, W. F., Kidd, R. B., Thomas, E., et al., Init. Repts. DSDP, 94, Pt. 2: Washington (U.S. Govt. Printing Office), 855-878.
Ruddiman, W. F., Raymo, M., and McIntyre, A., 1986b. Matuyama 41,000-year cycles: North Atlantic Ocean and Northern Hemisphere ice sheets. Earth Planet. Sci. Lett., 80:117-129.

Sager, W. W., 1986. Magnetic-susceptibility measurements of metal contaminants in ODP Leg 101 cores. In Austin, J. A., Jr., Schlager, W., Palmer, A. A., et al., Proc. ODP, Init. Repts., 101: College Station, TX (Ocean Drilling Program), 39-45.

1988. Paleomagnetism of Ocean Drilling Program Leg 101 sediments: magnetostratigraphy, magnetic diagenesis, and paleotides. In Austin, J. A., Jr., Schlager, W., Palmer, A. A., et al., Proc. ODP, Sci. Results, 101: College Station, TX (Ocean Drilling Program), 327-343.

Stoltz, J. F., Chang, S.-B. R., and Kirschvink, J. L., 1986. Magnetotactic bacteria and single-domain magnetite in hemipelagic sediments. Nature, 321:849-851.

Tauxe, L., and Wu, G., 1990. Normalized remanence in sediments of the western equatorial Pacific: relative paleointensity of the geomagnetic field? J. Geophys. Res., 95:12,337-12,350.

Thompson, R., Bloemendal, J., Dearing, J. A., Oldfield, F., Rummery, T. A., Stober, J. C., and Turner, G. M., 1980. Environmental applications of magnetic measurements. Science, 207:481-486.

Thompson, R., and Oldfield, F., 1986. Environmental Magnetism: New York (Allen and Unwin).

Worm, H.-U., and Weinreich, N., 1988. Rock magnetism of pelagic sediments from the equatorial Pacific. Earth Planet. Sci. Lett., 89:184192.

\section{Ms 130A-111}

\section{A}

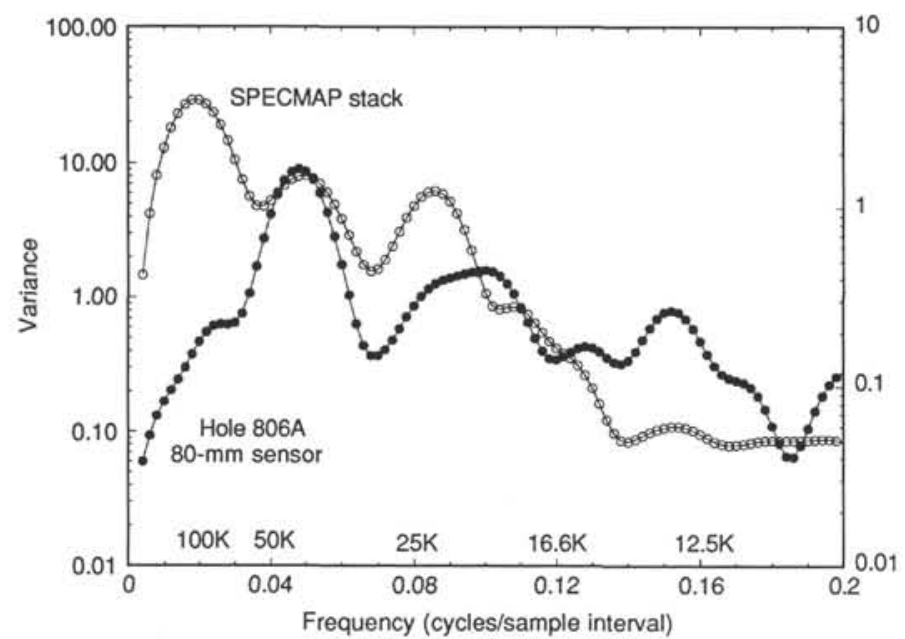

B

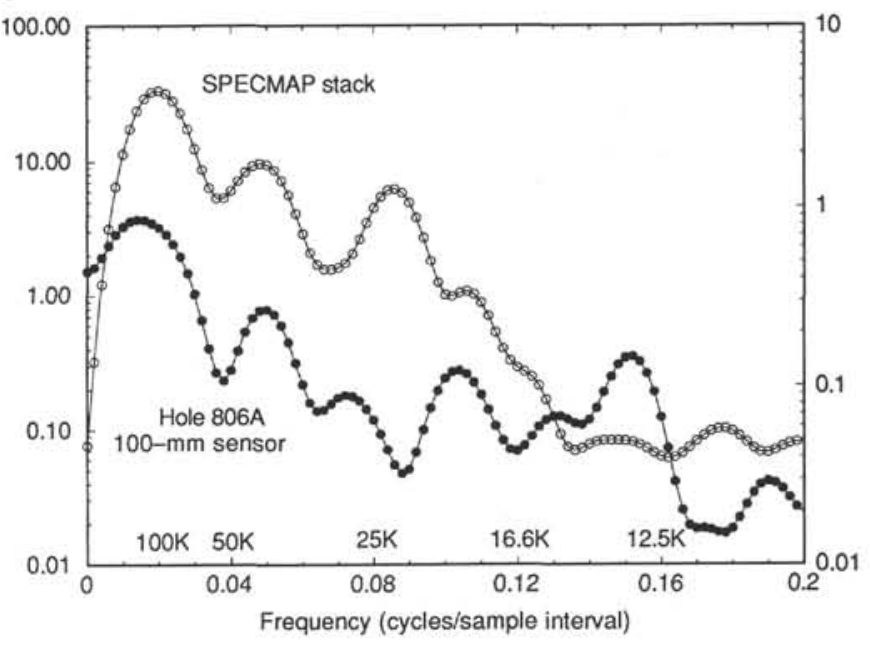

Figure 6. Spectral analysis of whole-core magnetic susceptibility data from Core 130-806A-4H between 27.0 and 36.0 mbsf using (A) the "high-resolution" 80-mm Bartington MS2C sensor and (B) the "low-resolution" 100-mm Bartington MS1C sensor. Also shown for comparison is the spectral analysis of the SPECMAP stack, which is a composite profile of Pleistocene isotopic data sets representing an ice-volume signal. Periodicity (in thousands of years) is shown above the frequency values. 


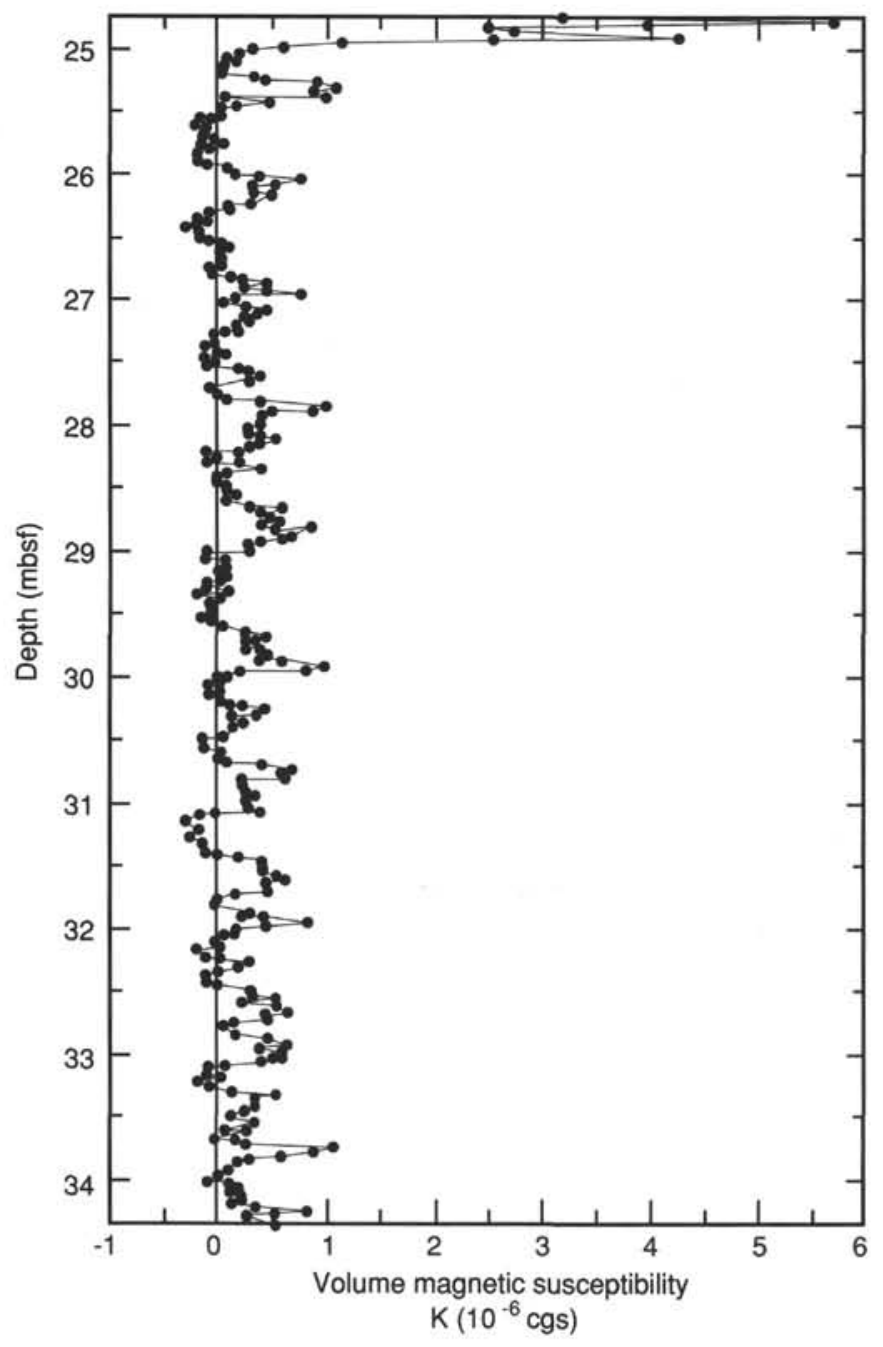

Figure 7. Whole-core magnetic susceptibility record from Core 130$806 \mathrm{C}-4 \mathrm{H}$ exhibiting cyclic variations similar to those observed in Core $130-806 \mathrm{~A}-4 \mathrm{H}$ over the same range of sub-bottom depths. High values above $25.0 \mathrm{mbsf}$ are probably caused by rust contamination at the core break.

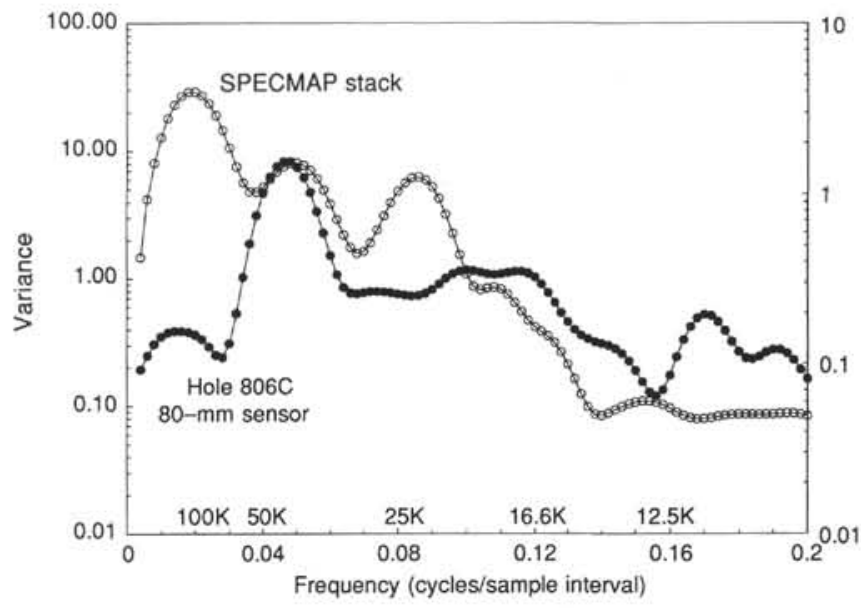

Figure 8. Spectral analyses of whole-core magnetic susceptibility data from Core 130-806C-4H between 25.0 and 34.0 mbsf using the "highresolution" 80 -mm Bartington sensor. Also shown for comparison is the spectral analysis of the SPECMAP stack, which is a composite profile of Pleistocene isotopic data sets representing an ice-volume signal. Periodicity (in thousands of years) is shown above the frequency values.

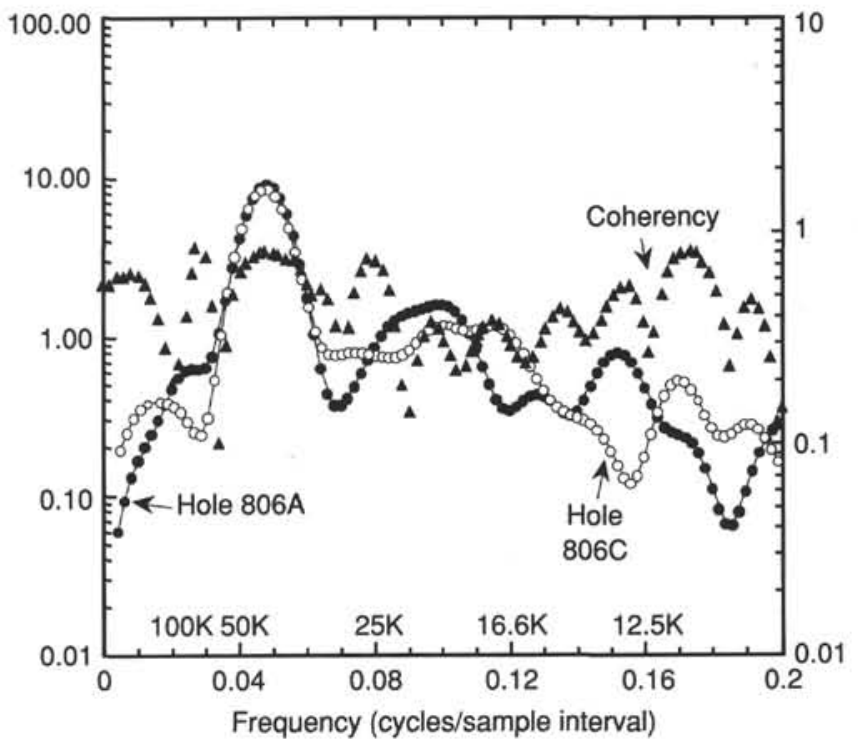

Figure 9. Cross correlation of "high-resolution" whole-core magnetic susceptibility records from Cores $130-806 \mathrm{~A}-4 \mathrm{H}$ and $130-806 \mathrm{C}-4 \mathrm{H}$. Periodicity (in thousands of years) is shown above the frequency values. 


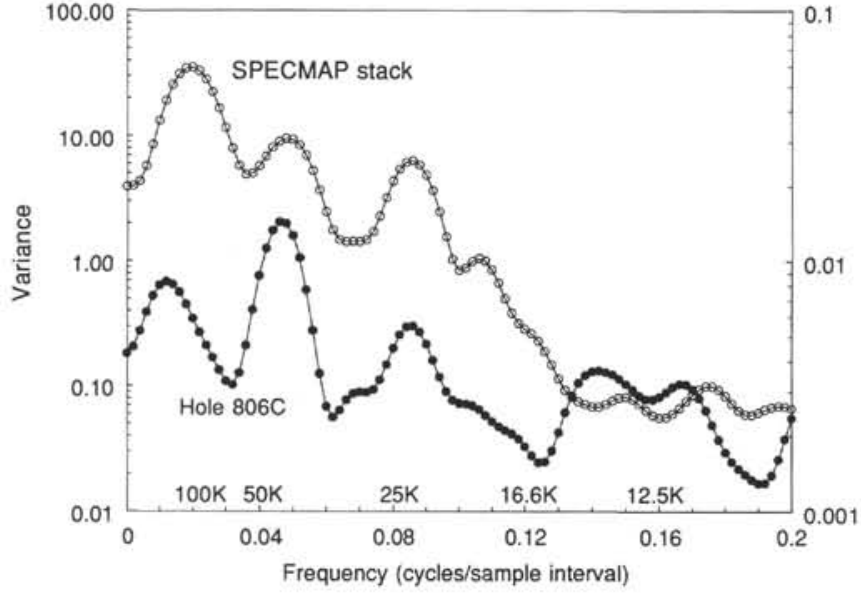

Figure 10. Spectral analyses of GRAPE data from Core $130-806 \mathrm{C}-4 \mathrm{H}$ between 25.0 and $34.0 \mathrm{mbsf}$. Also shown for comparison is the spectral analysis of the SPECMAP stack, which is a composite profile of Pleistocene isotopic data sets representing an ice-volume signal. Periodicity (in thousands of years) is shown above the frequency values.

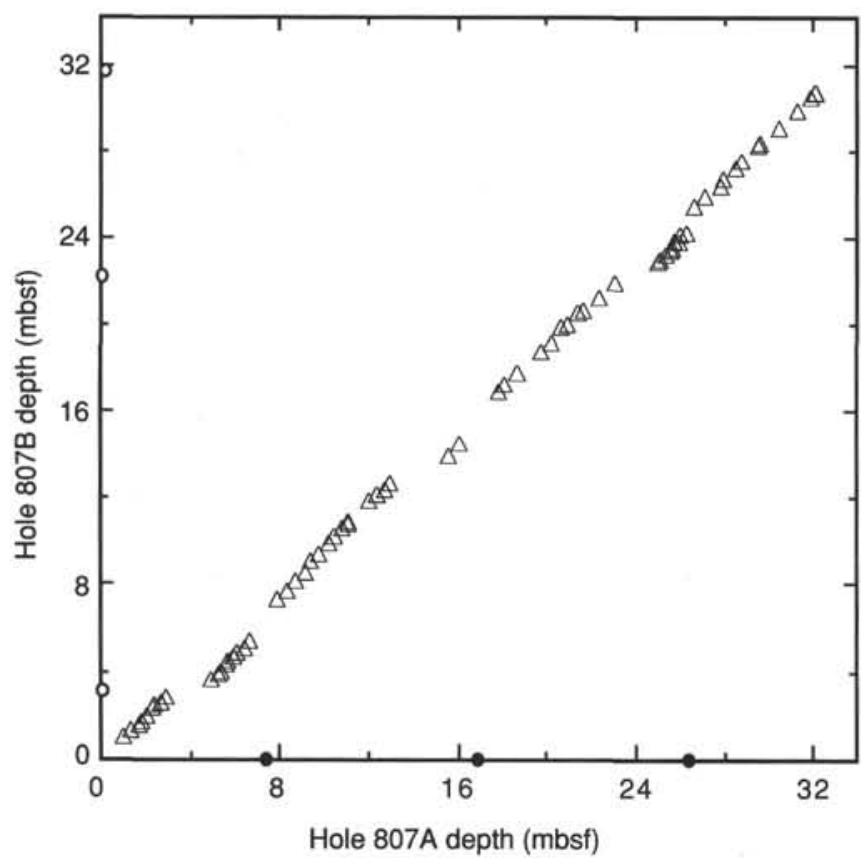

Figure 12. Correlation of Hole 807A and 807B using whole-core magnetic susceptibility data. Offsets in the correlation are caused by the loss of material at the core breaks (filled circles $=$ Hole 807A and open circles $=$ Hole 807B).
Table 4. Correlation between Holes 807A and 807B based upon whole-round magnetic susceptibility measurements.

\begin{tabular}{|c|c|c|c|c|c|c|}
\hline Correlation & Type & $\begin{array}{l}\text { Hole, } \\
\text { Core }\end{array}$ & $\begin{array}{l}\text { Depth } \\
\text { (mbsf) }\end{array}$ & $\begin{array}{l}\text { Hole, } \\
\text { Core }\end{array}$ & $\begin{array}{l}\text { Depth } \\
\text { (mbsf) }\end{array}$ & A-B \\
\hline Al & Peak & 807A-1H & 1.10 & $807 \mathrm{~B}-1 \mathrm{H}$ & 0.95 & 0.15 \\
\hline A2 & Trough & $807 \mathrm{~A}-1 \mathrm{H}$ & 1.43 & 807B-1H & 1.19 & 0.24 \\
\hline A3 & Trough & $807 \mathrm{~A}-1 \mathrm{H}$ & 1.73 & $807 \mathrm{~B}-1 \mathrm{H}$ & 1.49 & 0.24 \\
\hline A4 & Peak & 807A-1H & 1.85 & $807 \mathrm{~B}-1 \mathrm{H}$ & 1.67 & 0.18 \\
\hline A5 & Peak & $807 \mathrm{~A}-1 \mathrm{H}$ & 2.12 & $807 \mathrm{~B}-1 \mathrm{H}$ & 1.91 & 0.21 \\
\hline A6 & Trough & $807 \mathrm{~A}-1 \mathrm{H}$ & 2.39 & $807 \mathrm{~B}-1 \mathrm{H}$ & 2.12 & 0.27 \\
\hline A7 & Peak & $807 \mathrm{~A}-1 \mathrm{H}$ & 2.54 & $807 \mathrm{~B}-1 \mathrm{H}$ & 2.27 & 0.27 \\
\hline A8 & Trough & 807A-1H & 2.81 & $807 \mathrm{~B}-1 \mathrm{H}$ & 2.54 & 0.27 \\
\hline A9 & Peak & $807 \mathrm{~A}-1 \mathrm{H}$ & 2.96 & $\begin{array}{l}807 \mathrm{~B}-1 \mathrm{H} \\
\text { Core break }\end{array}$ & $\begin{array}{l}2.75 \\
3.10\end{array}$ & 0.21 \\
\hline B1 & Trough & $807 \mathrm{~A}-1 \mathrm{H}$ & 4.94 & $807 \mathrm{~B}-2 \mathrm{H}$ & 3.54 & 1.40 \\
\hline B2 & Trough & $807 \mathrm{~A}-1 \mathrm{H}$ & 5.33 & $807 \mathrm{~B}-2 \mathrm{H}$ & 3.87 & 1.46 \\
\hline B3 & Peak & $807 \mathrm{~A}-1 \mathrm{H}$ & 5.48 & $807 \mathrm{~B}-2 \mathrm{H}$ & 3.99 & 1.49 \\
\hline B4 & Trough & $807 \mathrm{~A}-1 \mathrm{H}$ & 5.72 & 807B-2H & 4.26 & 1.46 \\
\hline B5 & Peak & $807 \mathrm{~A}-1 \mathrm{H}$ & 5.87 & $807 \mathrm{~B}-2 \mathrm{H}$ & 4.44 & 1.43 \\
\hline B6 & Trough & 807A-1H & 6.11 & 807B-2H & 4.59 & 1.52 \\
\hline B7 & Peak & $807 \mathrm{~A}-1 \mathrm{H}$ & 6.20 & $807 \mathrm{~B}-2 \mathrm{H}$ & 4.77 & 1.43 \\
\hline B8 & Peak & $807 \mathrm{~A}-1 \mathrm{H}$ & 6.50 & 807B-2H & 5.04 & 1.46 \\
\hline \multirow[t]{2}{*}{ B9 } & Peak & $807 \mathrm{~A}-1 \mathrm{H}$ & 6.77 & $807 \mathrm{~B}-2 \mathrm{H}$ & 5.28 & 1.49 \\
\hline & & Core break & 7.40 & & & \\
\hline $\mathrm{Cl}$ & Peak & 807A-2H & 8.02 & $807 \mathrm{~B}-2 \mathrm{H}$ & 7.26 & 0.76 \\
\hline $\mathrm{C} 2$ & Peak & $807 \mathrm{~A}-2 \mathrm{H}$ & 8.44 & 807B-2H & 7.71 & 0.73 \\
\hline $\mathrm{C} 3$ & Peak & $807 \mathrm{~A}-2 \mathrm{H}$ & 8.80 & 807B-2H & 8.07 & 0.73 \\
\hline $\mathrm{C} 4$ & Peak & $807 \mathrm{~A}-2 \mathrm{H}$ & 9.22 & $807 \mathrm{~B}-2 \mathrm{H}$ & 8.49 & 0.73 \\
\hline C5 & Peak & 807A-2H & 9.55 & 807B-2H & 9.00 & 0.55 \\
\hline C6 & Peak & 807A-2H & 9.82 & 807B-2H & 9.24 & 0.58 \\
\hline C7 & Peak & $807 \mathrm{~A}-2 \mathrm{H}$ & 10.30 & 807B-2H & 9.78 & 0.52 \\
\hline C8 & Peak & $807 \mathrm{~A}-2 \mathrm{H}$ & 10.63 & 807B-2H & 10.14 & 0.49 \\
\hline C9 & Peak & $807 \mathrm{~A}-2 \mathrm{H}$ & 10.93 & $807 \mathrm{~B}-2 \mathrm{H}$ & 10.50 & 0.43 \\
\hline $\mathrm{C} 10$ & Trough & 807A-2H & 11.14 & $807 \mathrm{~B}-2 \mathrm{H}$ & 10.65 & 0.49 \\
\hline $\mathrm{C} 11$ & Peak & $807 \mathrm{~A}-2 \mathrm{H}$ & 11.23 & $807 \mathrm{~B}-2 \mathrm{H}$ & 10.77 & 0.46 \\
\hline $\mathrm{C} 12$ & Peak & $807 \mathrm{~A}-2 \mathrm{H}$ & 12.13 & 807B-2H & 11.70 & 0.43 \\
\hline $\mathrm{C} 13$ & Peak & $807 \mathrm{~A}-2 \mathrm{H}$ & 12.52 & 807B-2H & 12.06 & 0.46 \\
\hline $\mathrm{C} 14$ & Peak & $807 \mathrm{~A}-2 \mathrm{H}$ & 12.82 & 807B-2H & 12.30 & 0.52 \\
\hline \multirow[t]{2}{*}{ C15 } & Peak & $807 \mathrm{~A}-2 \mathrm{H}$ & 13.09 & $807 \mathrm{~B}-2 \mathrm{H}$ & 12.57 & 0.52 \\
\hline & & & & Core break & 12.60 & \\
\hline D1 & Peak & $807 \mathrm{~A}-2 \mathrm{H}$ & 15.70 & 807B-3H & 13.82 & 1.88 \\
\hline \multirow[t]{2}{*}{ D2 } & Peak & $807 \mathrm{~A}-2 \mathrm{H}$ & 16.12 & $807 \mathrm{~B}-3 \mathrm{H}$ & 14.30 & 1.82 \\
\hline & & Core break & 16.90 & & & \\
\hline E1 & Trough & $807 \mathrm{~A}-3 \mathrm{H}$ & 18.00 & $807 \mathrm{~B}-3 \mathrm{H}$ & 16.79 & 1.21 \\
\hline E2 & Peak & $807 \mathrm{~A}-3 \mathrm{H}$ & 18.24 & 807B-3H & 17.06 & 1.18 \\
\hline E3 & Peak & $807 \mathrm{~A}-3 \mathrm{H}$ & 18.84 & $807 \mathrm{~B}-3 \mathrm{H}$ & 17.66 & 1.18 \\
\hline $\mathrm{E} 4$ & Trough & $807 \mathrm{~A}-3 \mathrm{H}$ & 19.89 & $807 \mathrm{~B}-3 \mathrm{H}$ & 18.59 & 1.30 \\
\hline E5 & Peak & $807 \mathrm{~A}-3 \mathrm{H}$ & 20.31 & $807 \mathrm{~B}-3 \mathrm{H}$ & 19.04 & 1.27 \\
\hline E6 & Trough & 807A-3H & 20.85 & 807B-3H & 19.61 & 1.24 \\
\hline E7 & Peak & $807 \mathrm{~A}-3 \mathrm{H}$ & 21.09 & 807B-3H & 19.85 & 1.24 \\
\hline E8 & Trough & $807 \mathrm{~A}-3 \mathrm{H}$ & 21.57 & $807 \mathrm{~B}-3 \mathrm{H}$ & 20.30 & 1.27 \\
\hline E9 & Peak & $807 \mathrm{~A}-3 \mathrm{H}$ & 21.81 & $807 \mathrm{~B}-3 \mathrm{H}$ & 20.54 & 1.27 \\
\hline E10 & Peak & 807A-3H & 22.41 & 807B-3H & 21.08 & 1.33 \\
\hline \multirow[t]{2}{*}{ E11 } & Peak & $807 \mathrm{~A}-3 \mathrm{H}$ & 23.13 & $807 \mathrm{~B}-3 \mathrm{H}$ & 21.74 & 1.39 \\
\hline & & & & Core break & 22.10 & \\
\hline F1 & Peak & $807 \mathrm{~A}-3 \mathrm{H}$ & 25.08 & $807 \mathrm{~B}-4 \mathrm{H}$ & 22.60 & 2.48 \\
\hline F2 & Peak & $807 \mathrm{~A}-3 \mathrm{H}$ & 25.26 & 807B-4H & 22.81 & 2.45 \\
\hline F3 & Peak & $807 \mathrm{~A}-3 \mathrm{H}$ & 25.56 & 807B-4H & 23.14 & 2.42 \\
\hline F4 & Trough & $807 \mathrm{~A}-3 \mathrm{H}$ & 25.68 & $807 \mathrm{~B}-4 \mathrm{H}$ & 23.23 & 2.45 \\
\hline F5 & Peak & $807 \mathrm{~A}-3 \mathrm{H}$ & 25.83 & $807 \mathrm{~B}-4 \mathrm{H}$ & 23.38 & 2.45 \\
\hline F6 & Trough & $807 \mathrm{~A}-3 \mathrm{H}$ & 25.89 & $807 \mathrm{~B}-4 \mathrm{H}$ & 23.59 & 2.30 \\
\hline F7 & Peak & $807 \mathrm{~A}-3 \mathrm{H}$ & 25.98 & $807 \mathrm{~B}-4 \mathrm{H}$ & 23.68 & 2.30 \\
\hline F8 & Trough & $807 \mathrm{~A}-3 \mathrm{H}$ & 26.19 & $807 \mathrm{~B}-4 \mathrm{H}$ & 23.83 & 2.36 \\
\hline \multirow[t]{2}{*}{ F9 } & Peak & $807 \mathrm{~A}-3 \mathrm{H}$ & 26.37 & $807 \mathrm{~B}-4 \mathrm{H}$ & 24.01 & 2.36 \\
\hline & & Core break & 26.40 & & & \\
\hline G1 & Peak & $807 \mathrm{~A}-4 \mathrm{H}$ & 26.78 & $807 \mathrm{~B}-4 \mathrm{H}$ & 25.21 & 1.57 \\
\hline G2 & Peak & $807 \mathrm{~A}-4 \mathrm{H}$ & 27.26 & $807 \mathrm{~B}-4 \mathrm{H}$ & 25.69 & 1.57 \\
\hline G3 & Trough & $807 \mathrm{~A}-4 \mathrm{H}$ & 27.89 & $807 \mathrm{~B}-4 \mathrm{H}$ & 26.26 & 1.63 \\
\hline G4 & Peak & $807 \mathrm{~A}-4 \mathrm{H}$ & 28.07 & $807 \mathrm{~B}-4 \mathrm{H}$ & 26.50 & 1.57 \\
\hline G5 & Trough & $807 \mathrm{~A}-4 \mathrm{H}$ & 28.64 & $807 \mathrm{~B}-4 \mathrm{H}$ & 26.98 & 1.66 \\
\hline G6 & Peak & $807 \mathrm{~A}-4 \mathrm{H}$ & 28.85 & $807 \mathrm{~B}-4 \mathrm{H}$ & 27.25 & 1.60 \\
\hline G7 & Peak & $807 \mathrm{~A}-4 \mathrm{H}$ & 29.60 & $807 \mathrm{~B}-4 \mathrm{H}$ & 28.00 & 1.60 \\
\hline G8 & Trough & $807 \mathrm{~A}-4 \mathrm{H}$ & 29.72 & $807 \mathrm{~B}-4 \mathrm{H}$ & 28.09 & 1.63 \\
\hline G9 & Peak & $807 \mathrm{~A}-4 \mathrm{H}$ & 30.53 & 807B-4H & 28.84 & 1.69 \\
\hline G10 & Peak & $807 \mathrm{~A}-4 \mathrm{H}$ & 31.40 & $807 \mathrm{~B}-4 \mathrm{H}$ & 29.68 & 1.72 \\
\hline G11 & Peak & $807 \mathrm{~A}-4 \mathrm{H}$ & 32.12 & $807 \mathrm{~B}-4 \mathrm{H}$ & 30.31 & 1.81 \\
\hline G12 & Trough & $807 \mathrm{~A}-4 \mathrm{H}$ & 32.18 & 807B-4H & 30.40 & 1.78 \\
\hline \multirow[t]{2}{*}{ G13 } & Peak & $807 \mathrm{~A}-4 \mathrm{H}$ & 32.27 & $807 \mathrm{~B}-4 \mathrm{H}$ & 30.46 & 1.81 \\
\hline & & & & Core break & 31.60 & \\
\hline
\end{tabular}

Note: See Figure 11 for locations of correlative peaks and troughs. 


\section{J. A. TARDUNO ET AL.}

Table 5. Correlation between Holes $807 \mathrm{~A}, 805 \mathrm{C}$, and $806 \mathrm{~A}$ based upon whole-round magnetic susceptibility measurements.

\begin{tabular}{clccccccrrr}
\hline Correlation & Type & $\begin{array}{c}\text { Hole, } \\
\text { Core }\end{array}$ & $\begin{array}{c}\text { Depth } \\
\text { (mbsf) }\end{array}$ & $\begin{array}{c}\text { Hole, } \\
\text { Core }\end{array}$ & $\begin{array}{c}\text { Depth } \\
(\mathrm{mbsf})\end{array}$ & $\begin{array}{c}\text { Hole, } \\
\text { Core }\end{array}$ & $\begin{array}{r}\text { Depth } \\
(\mathrm{mbsf})\end{array}$ & $\begin{array}{c}807-805 \\
(\mathrm{~m})\end{array}$ & $\begin{array}{c}807-806 \\
(\mathrm{~m})\end{array}$ & $\begin{array}{c}805-806 \\
(\mathrm{~m})\end{array}$ \\
\hline A1 & Peak & $807 \mathrm{~A}-1 \mathrm{H}$ & 0.41 & $805 \mathrm{C}-1 \mathrm{H}$ & 0.41 & $806 \mathrm{~A}-1 \mathrm{H}$ & 0.38 & 0.00 & 0.03 & 0.03 \\
A2 & Peak & $807 \mathrm{~A}-1 \mathrm{H}$ & 1.10 & $805 \mathrm{C}-1 \mathrm{H}$ & 1.10 & $806 \mathrm{~A}-1 \mathrm{H}$ & 0.89 & 0.00 & 0.21 & 0.21 \\
A3 & Trough & $807 \mathrm{~A}-1 \mathrm{H}$ & 1.43 & $805 \mathrm{C}-1 \mathrm{H}$ & 1.49 & $806 \mathrm{~A}-1 \mathrm{H}$ & 1.49 & -0.06 & -0.06 & 0.00 \\
A4 & Peak & $807 \mathrm{~A}-1 \mathrm{H}$ & 1.67 & $805 \mathrm{C}-1 \mathrm{H}$ & 1.73 & $806 \mathrm{~A}-1 \mathrm{H}$ & - & -0.06 & - & - \\
A5 & Trough & $807 \mathrm{~A}-1 \mathrm{H}$ & 1.73 & $805 \mathrm{C}-1 \mathrm{H}$ & 1.82 & $806 \mathrm{~A}-1 \mathrm{H}$ & - & -0.09 & - \\
A6 & Peak & $807 \mathrm{~A}-1 \mathrm{H}$ & 1.85 & $805 \mathrm{C}-1 \mathrm{H}$ & 1.97 & $806 \mathrm{~A}-1 \mathrm{H}$ & 2.61 & -0.12 & -0.76 & -0.64 \\
A7 & Peak & $807 \mathrm{~A}-1 \mathrm{H}$ & 2.12 & $805 \mathrm{C}-1 \mathrm{H}$ & 2.39 & $806 \mathrm{~A}-1 \mathrm{H}$ & 2.93 & -0.27 & -0.81 & -0.54 \\
A8 & Trough & $807 \mathrm{~A}-1 \mathrm{H}$ & 2.39 & $805 \mathrm{C}-1 \mathrm{H}$ & 2.54 & $806 \mathrm{~A}-1 \mathrm{H}$ & 3.17 & -0.15 & -0.78 & -0.63 \\
A9 & Peak & $807 \mathrm{~A}-1 \mathrm{H}$ & 2.54 & $805 \mathrm{C}-1 \mathrm{H}$ & 2.81 & $806 \mathrm{~A}-1 \mathrm{H}$ & 3.41 & -0.27 & -0.87 & -0.60 \\
A10 & Peak & $807 \mathrm{~A}-1 \mathrm{H}$ & 3.11 & $805 \mathrm{C}-1 \mathrm{H}$ & 3.35 & $806 \mathrm{~A}-1 \mathrm{H}$ & 4.40 & -0.24 & -1.29 & -1.05 \\
A11 & Peak & $807 \mathrm{~A}-1 \mathrm{H}$ & 3.80 & $805 \mathrm{C}-1 \mathrm{H}$ & 4.04 & $806 \mathrm{~A}-1 \mathrm{H}$ & 5.30 & -0.24 & -1.50 & -1.26 \\
A12 & Peak & $807 \mathrm{~A}-1 \mathrm{H}$ & 4.58 & $805 \mathrm{C}-1 \mathrm{H}$ & 4.79 & $806 \mathrm{~A}-1 \mathrm{H}$ & 6.35 & -0.21 & -1.77 & -1.56 \\
A13 & Trough & $807 \mathrm{~A}-1 \mathrm{H}$ & 4.85 & $805 \mathrm{C}-1 \mathrm{H}$ & 4.94 & $806 \mathrm{~A}-1 \mathrm{H}$ & - & -0.09 & - & - \\
A14 & Peak & $807 \mathrm{~A}-1 \mathrm{H}$ & 5.48 & $805 \mathrm{C}-1 \mathrm{H}$ & 5.63 & $806 \mathrm{~A}-1 \mathrm{H}$ & - & -0.15 & - \\
\hline
\end{tabular}

Note: See Figure 13 for locations of correlative peaks and troughs. 